DOI: 10.20472/IAC.2017.028.020

\author{
JOHAN WINBLADH
}

Webster University, Vienna, Austria, Slovak Republic

\title{
SYSTEMIC BANKING CRISIS AND MACROECONOMIC LEADING INDICATORS
}

\begin{abstract}
:
The purpose of this study is to identify leading macroeconomic indicators causing or coinciding with systemic banking crises. The clear focus on systemic banking crisis leave little ambiguity of what constitutes a banking crisis. The macroeconomic leading indicators are chosen with economic theory in mind. The indicators are tested using multivariate regression with a dichotomous variable for systemic banking crisis or no systemic banking crisis. The results shows that inflation is the strongest leading indicator coinciding with systemic banking crisis in both advanced economies as well as in South American middle income economies. Inflation is a broad indicator of general economic difficulties as well as for policy related issues.
\end{abstract}

\section{Keywords:}

Systemic banking crisis, multivariate regression analysis, macroeconomic leading indicators, and macroeconomic fundamental problems.

JEL Classification: G01, C58, E44 


\section{Introduction}

Systemic banking crisis is an example of extreme turbulence in the financial markets. Researching systemic banking crisis is helpful, since it can lead to a higher level of predictability and better policy responses. The importance of predicting and mitigating systemic banking crisis cannot be underestimated given the impact on an economy in the form of falling aggregated output with the problems it brings along.

For example, in the great American Recession from December 2007 to July 2009, unemployment increased by seven percent over normal down phase cycle unemployment, government debt increases due to both direct cost of the crisis as well as a smaller GDP base. The situation was similar in other countries hit by the crisis (Reinhart, \& Rogoff, 2009).

The example above illustrates the importance of learning more about financial crisis, its causes and policy implications.

Both in developed and developing, emerging economies, systemic banking crisis occurs within regular intervals. The number of systemic banking crisis since 1970 to 2011 amounts to 147 (Laeven, \& Valencia, 2013).

A common scenario of banking crisis is that there are imbalances built up in assets, creating asset bubbles. The asset bubbles often are fueled by a rapid credit expansion and possibly capital inflow (Reinhart, \& Rogoff, 2013).

To determine which macroeconomic leading indicators that causes systemic banking crisis is difficult, consequently for stringency it is preferably to examine leading macroeconomic indicators that precede and/or coincide with systemic banking crisis.

The study uses a multinomial linear regression with a dichotomous variable for systemic banking crisis or no systemic banking crisis. That means that a country with a banking crisis in a specific year is indicated with a 1 and if ether is no banking crisis for a given country in a specific year it is marked with a 0 . 


\section{The testing}

The data used for the empirical study is available at the World Bank's database (The World Bank, n.d.). The data are sorted into a pooled time series with data from 19902015 for the chosen, macroeconomic leading indicators and the countries tested. The test is done with a linear multivariate regression in STATA a statistical analysis software package. The countries tested are a mix of advanced economies and South American countries. The countries have been chosen to reflect a distinct region, South America as well as different types of economies, advanced and middle income. Seven middle income economies in South America are chosen mainly due to data availability. For the advanced economies the sample contains 24 countries from around the world. The advanced economies and the South American middle income economies are tested separately to clearly establish if there are any differences, and similarities in regards to leading macroeconomic indicators and the propensity to systemic banking crisis. The two separate samples have enough crisis and non-crisis periods to facilitate the research.

Table (1)

\begin{tabular}{|c|c|c|c|}
\hline $\begin{array}{l}\text { South } \\
\text { America }\end{array}$ & \multicolumn{3}{|l|}{ Advanced } \\
\hline 1. Argentina & 1. Austria & $\begin{array}{l}9 . \\
\text { Netherlands }\end{array}$ & 17. Ireland \\
\hline 2. Brazil & 2. Belgium & 10. Spain & 18. Iceland \\
\hline 3. Chile & 3. Denmark & 11. Sweden & 19. Israel \\
\hline 4. Colombia & 4. Finland & 12. Greece & 20. Japan \\
\hline 5. Ecuador & 5. France & 13. USA & 21. Norway \\
\hline 6. Honduras & 6. Germany & 14. Australia & $\begin{array}{ll}22 . \quad N e w \\
\text { Zealand }\end{array}$ \\
\hline \multirow[t]{3}{*}{ 7. Peru } & $\begin{array}{l}\text { 7. Great } \\
\text { Britain }\end{array}$ & 15. Canada & 23. Portugal \\
\hline & 8. Italy & $\begin{array}{ll}16 . & \text { Hong } \\
\text { Kong } & \end{array}$ & 24. Singapore \\
\hline & & & \# 31 \\
\hline
\end{tabular}

The leading macroeconomic indicators are chosen from the framework of economics and finance in their regards to being involved in a systemic banking crisis. The question 
at hand is what leading macroeconomic indicators do coincide with systemic banking crisis? Borio and Drehmann (2009), have thoroughly researched and explained leading macroeconomic indicators.

The leading indicators chosen fit into the theory of a weakening or strengthening of a country's and its banks economic situation. The development of the leading macroeconomic follows Frankel and Saravelos, (2010) study of the subprime crisis and following Great Recession. They on the other hand was inspired by Hawkins and Klau (2000) who studied financial crisis in emerging markets from 1990 to 1998 using leading macroeconomic indicators. Following the meta-study of the two above mentioned studies the indicators chosen for this study is in line with the current knowledge in regards to macroeconomic leading indicators. Given the result of several studies, but mainly the meta-study of 83 papers covering leading indicators by Frankel and Saravelos, (2010) the following macroeconomic leading indicators was chosen:

Table (2)

Definition of the binary, dichotomous dependent variable and the leading indicators used

\begin{tabular}{|l|l|l|}
\hline Variable & Leading indicators and definition & $\begin{array}{l}\text { Expected } \\
\text { sign }\end{array}$ \\
\hline bc & $\begin{array}{l}\text { Banking crisis with value of 1 for the crisis and 0 } \\
\text { otherwise }\end{array}$ & $\mathrm{n} / \mathrm{a}$ \\
\hline gdp & $\begin{array}{l}\text { Gross domestic product of a country. Measured at } \\
\text { purchaser's prices }\end{array}$ & + \\
\hline gdpg & $\begin{array}{l}\text { Growth of the economy measured with GDP } \\
\text { growth as the annual percentage change in GDP } \\
\text { in local constant currency }\end{array}$ & + \\
\hline cpi & $\begin{array}{l}\text { Inflation as in change in consumer prices } \\
\text { measured with CPI in local constant currency }\end{array}$ & - \\
\hline rer & $\begin{array}{l}\text { The percentage change in the Exchange Rate. } \\
\text { Year 2010 is the base year and set at 100 }\end{array}$ & + \\
\hline dc & $\begin{array}{l}\text { Domestic credit from financial sector in percent of } \\
\text { GDP }\end{array}$ & - \\
\hline cagdp & Current account deficit surplus in percent of GDP & - \\
\hline
\end{tabular}




\begin{tabular}{|l|l|l|}
\hline $\mathrm{m} 3 \mathrm{~g}$ & Growth of M3 & - \\
\hline $\mathrm{pbd}$ & Government debt in percent of GDP & - \\
\hline degp & External debt in percent of GNI & - \\
\hline resgdp & Central bank reserves in percent of GDP & + \\
\hline
\end{tabular}

The leading indicators chosen fit into the theory of a weakening or strengthening of a country's and its banks economic situation. The results from the testing for the advanced economies and for the South American middle income countries give us insight into the data set through the descriptive statistic as well as knowledge about the macroeconomic leading indicators prevalence in systemic banking crisis. What is unique with this study is the choice of two different composites of countries, advanced and South American middle income economies. The second is the long time span from 1990 to 2015. Thirdly, the clear focus on one type of crisis, systemic banking crisis only.

\section{Results from the empirical testing}

\subsection{Results, advanced economies}

In the following table the descriptive statistics for the advanced economies are found. Table (3)

Descriptive statistics for advanced economies (1990-2015)

\begin{tabular}{|l|l|l|l|l|l|}
\hline Var & Obs & Mean & Std. Dev. & Min & Max \\
\hline gdpg & 623 & 2.387384 & 2.795834 & -9.132494 & 15.24 \\
\hline cpi & 623 & 2.65776 & 2.720436 & -4.48 & 20.40457 \\
\hline rer & 597 & 99.94437 & 11.70124 & 66.82827 & 152.7756 \\
\hline dc & 598 & 114.0601 & 62.57679 & 26.64071 & 376.9547 \\
\hline cagdp & 556 & 0.9326404 & 6.296444 & -23.66981 & 26.10381 \\
\hline m3g & 315 & 105.2627 & 66.87311 & 33.64951 & 362.2442 \\
\hline pbd & 296 & 60.43692 & 34.54968 & 5.656847 & 201.5677 \\
\hline resgdp & 623 & 13.82689 & 21.69912 & 0.3431318 & 120.8403 \\
\hline
\end{tabular}

In the table, (table 2), above there not that many extreme values which is not surprising since advanced economies rarely suffer hyperinflation or extreme movement of exchange rates. Some exceptions may include, Iceland, Ireland and Greece. Greece for example, saw their GDP shrink by over $9 \%$ in 2011. Singapore on the other hand 
had growth of over $15 \%$ in 2010 . Greece had an inflation rate of more than $20 \%$ in 1990 . Australia's real exchange rate was down at almost 67 in 2001, base year is 2010 at 100 . The relatively low value of the Australian dollar is explained partially by Australia's lower interest rates compared to the rest of the sample countries. The low interest makes the Australian dollar a less attractive investment. The other more important factor is; the terms of trade, as Australia exports mainly raw material, which have volatile world market prices (Chen, \& Rogoff, 2003). In 1994, Greece had the lowest domestic credit in the sample. Since then their indebtedness has increased a lot. Iceland stands for the biggest current account deficit and it occurs in 2008. Portugal has the smallest government debt at less than 6\% in 1994 and Japan the largest at over 200\% in 2013. Since the extreme values for "central bank reserves" are the same as for "all countries", the lowest value is for Ireland in, 2007, and the highest value is for Hong Kong, in 2012. All data can be found at the World Banks data base for indicators World Bank. (n.d.). Table (4)

Results of panel linear probability regression for advanced economies (19902015)

\begin{tabular}{|c|c|c|c|c|c|c|}
\hline Variable & Coef. & Std. Err. & $\mathbf{t}$ & $P>t$ & \multicolumn{2}{|c|}{ [95\% Conf. Interval] } \\
\hline gdpg & & 0.0093116 & -1.33 & 0.187 & -0.030746 & 0.006055 \\
\hline cpi & 0.0205536 & 0.0107851 & 1.91 & 0.059 & -0.000759 & 0.041866 \\
\hline rer & $\begin{array}{l}- \\
0.0067436\end{array}$ & 0.0030409 & -2.22 & 0.028 & -0.012752 & -0.00073 \\
\hline dc & $\begin{array}{l}- \\
0.0000354\end{array}$ & 0.0008298 & -0.04 & 0.966 & -0.001675 & 0.001604 \\
\hline cagdp & $\begin{array}{l}- \\
0.0214008\end{array}$ & 0.00662 & -3.23 & 0.002 & -0.034482 & -0.00831 \\
\hline $\mathrm{pbd}$ & 0.6850136 & 7.348562 & 0.09 & 0.926 & -13.83664 & 15.20667 \\
\hline resgdp & 0.0002038 & 0.0045685 & 0.04 & 0.964 & -0.008824 & 0.009231 \\
\hline cons & 1.108564 & 0.3562559 & 3.11 & 0.002 & 0.4045586 & 1.812569 \\
\hline
\end{tabular}

\section{R-squared 0.18}


The regression in table 4 tested the leading macroeconomic listed in the table. For the advanced economies, public debt is used instead of external debt as for the South American countries. This choice of changing one of the leading indicators is based on data availability.

The results for the advanced economies (table 4) suggest the following:

- Consumer price index, which is a measure of macroeconomic stability, seems to have played a significant role in explaining the occurrence of a systemic banking crisis in advanced economies. This is consistent with the results of (DemirgüçKunt, \& Detragiache, (1998) for developing countries however. Since inflation is indicated also for advanced economies, it is possible that inflation is a more universal macroeconomic leading indicator for systemic banking crisis.

- A strong currency is indicated by the real exchange rate and the countries with a high level of real exchange rate are more competitive and therefore less prone to systemic banking crisis. The European currency crisis in the early 1990 when several European countries had to give up their peg against the ECU is a good recent example. (Obstfeld, 1996). As earlier stated the countries that had to give up the peg of their currency exchange rate against the ECU basket all ran a higher inflation than their major trading partners in Europe. The real exchange rate deteriorated and the consequently suffered from systemic banking crisis. What the expected sign should be is up for further discussion. However if the real exchange rate is increasing due to strengths it indicates a lower risk of systemic banking crisis. An artificially high real exchange rate however, like under a fixed exchange regime or within the Eurozone is likely to cause a crisis like in Greece, (Hall, 2012), or a currency crisis like the ERM crisis from the early 1990s (Buiter, Corsetti, \& Pesenti, 1997).

- Likewise, the coefficient on the current account balance indicates that systemic banking crisis is a phenomenon of countries with current account deficits. This factor does not bear the expected sign, and therefore failed to significantly explain a systemic banking crisis. However the countries most severely affected by the European sovereign debt crisis had a significantly large current account 
deficit in percent of GDP both prior to the crisis and during the early part of the crisis (Giavazzi, \& Spaventa, 2011).

- The other variables remain statistically insignificant and therefore their impact on systemic banking crisis remains unclear. Worth mentioning is that the amount of government debt does not seem to be a likely cause of banking crises in the advanced economies which indicates that advanced economies can be debt ridden and still function. Worth mentioning is that too much sovereign debt do lower GDP growth as Reinhart, and Rogoff, (2010) found out in their central study, Growth in Time of Debt.

\subsection{Results, South American middle income economies}

The results in the following descriptive statistics table summarizes the data for the South American middle income economies in the study.

Table (5)

Descriptive statistics for South America (1990-2015)

\begin{tabular}{|l|l|l|l|l|l|}
\hline Variable & Obs & Mean & \multicolumn{1}{|c|}{ Std. Dev. } & Min & Max \\
\hline gdpg & 287 & 3.253346 & 3.938419 & -12.312 & 12.66971 \\
\hline cpi & 285 & 126.9699 & 594.1265 & -1.17 & 7481.66 \\
\hline rer & 180 & 97.40177 & 25.30782 & 55.39963 & 199.3012 \\
\hline dc & 282 & 46.90753 & 29.27081 & 10.52891 & 212.9187 \\
\hline ca & 263 & $-5.65 \mathrm{E}+09$ & $1.36 \mathrm{E}+10$ & $-1.04 \mathrm{E}+11$ & $1.40 \mathrm{E}+10$ \\
\hline cagdp & 262 & -2.849647 & 3.521263 & -15.44524 & 8.970738 \\
\hline m3g & 284 & 36.31648 & 18.34013 & 10.0829 & 111.3253 \\
\hline degp & 210 & 48.17173 & 27.34768 & 15.71577 & 147.5599 \\
\hline resgdp & 287 & 10.60157 & 6.676853 & 0.7721734 & 33.29231 \\
\hline
\end{tabular}

The descriptive statistics for South America are interesting. The variability in GDP growth is not that large, from -12.3 to +12.7 percent. In the advanced economies of 24 countries, a much larger sample, it varied between -9.1 and +15.2 percent. The worst GDP decline is in Peru in 1990 which also has hyperinflation at the time with $7500 \%$ inflation. Argentina has the highest growth and it is in year 1991, which is the same year they pegged the peso to the dollar. The inflationary pressure was not off in Argentina, 
but at least lower. Still the peg of the Argentinian peso to the dollar could not hold. It is interesting that in the first year of the peg Argentina had the highest growth. (Feldstein, 2002). The real exchange rate is very depressed at 55 for Brazil in 2003. Ecuador has the highest real exchange rate at 199. The lowest domestic credit is found in Ecuador in 1990 at just over $10 \%$, the highest in Brazil at $213 \%$ of GDP. The lowest current account to GDP in percent is found in Honduras in 2008. In 2002 Argentina has the highest current account surplus to GDP ratio in the sample of South American countries. Argentina followed up with five years of uninterrupted growth, which the country badly needed (Frenkel, \& Rapetti, 2008). Money supply to GDP ratio is linked to inflation. Brazil got the lowest and highest money supply to GDP. The external debt varies from $15.7 \%$ to $147 \%$. It is a large variation and Brazil has the least debt of all countries in the whole sample and that is in year 2011. Brazil had fast growth from 2004 to 2008. Honduras has the most external debt in the sample and it occurs in 1994. The central bank reserves are the lowest for Honduras. Peru has the highest central bank reserves of all countries in 2012. A reason can be that Peru learned from the debacle of the previous government (Rojas-Suarez, \& Weisbrod, 1996).

Table (6)

Results of linear probability regression for South America (1990-2015)

\begin{tabular}{|l|c|l|l|l|l|l|}
\hline Variable & Coef. & Std. Err. & $\mathbf{t}$ & $\mathbf{P}>\mathbf{t}$ & \multicolumn{2}{|c|}{ [95\% Conf. Interval] } \\
\hline gdpg & -0.01241 & 0.01308 & -0.95 & 0.345 & -0.038367 & 0.0135409 \\
\hline cpi & $\mathbf{0 . 0 0 0 2 2 6}$ & $\mathbf{0 . 0 0 0 1 2}$ & $\mathbf{1 . 8 9}$ & $\mathbf{0 . 0 6 2}$ & $\mathbf{- 0 . 0 0 0 0 1 1}$ & $\mathbf{0 . 0 0 0 4 6 3 9}$ \\
\hline rer & $\mathbf{0 . 0 0 8 6 0 6}$ & $\mathbf{0 . 0 0 2 0 6}$ & $\mathbf{4 . 1 9}$ & $\mathbf{0}$ & $\mathbf{0 . 0 0 4 5 2 6}$ & $\mathbf{0 . 0 1 2 6 8 5 9}$ \\
\hline dc & -0.00180 & 0.00429 & -0.42 & 0.674 & -0.010307 & 0.0066973 \\
\hline cagdp & $\mathbf{0 . 0 3 5 3 9 3}$ & $\mathbf{0 . 0 1 5 3 9}$ & $\mathbf{2 . 3}$ & $\mathbf{0 . 0 2 4}$ & $\mathbf{0 . 0 0 4 8 5 4}$ & $\mathbf{0 . 0 6 5 9 3 2 9}$ \\
\hline m3g & 0.002144 & 0.00653 & 0.33 & 0.743 & -0.010816 & 0.0151057 \\
\hline degp & $\mathbf{0 . 0 0 8 9 0 4}$ & $\mathbf{0 . 0 0 3 6 8}$ & $\mathbf{2 . 4 2}$ & $\mathbf{0 . 0 1 7}$ & $\mathbf{0 . 0 0 1 5 9 7}$ & $\mathbf{0 . 0 1 6 2 1 1}$ \\
\hline resgdp & $\mathbf{- 0 . 0 3 4 0 5}$ & $\mathbf{0 . 0 1 6 7 1}$ & $\mathbf{- 2 . 0 4}$ & $\mathbf{0 . 0 4 4}$ & $\mathbf{0 . 0 6 7 2 1 1}$ & $\mathbf{- 0 . 0 0 0 9 0 6}$ \\
\hline cons & -0.62323 & 0.31949 & -1.95 & 0.054 & -1.257094 & 0.0106332 \\
\hline
\end{tabular}

\section{R-squared 0.50}

The result from the regression of the South American countries are found in table 6 . The linear multivariate regression tested, the possible macroeconomic leading indicators and the propensity of systemic banking crisis. The result is quite astonishing with inflation, real exchange rate, current account deficit and external debt increasing the 
risk of a systemic banking crisis. To add on to the textbook finding is that the larger the central bank's reserves the less of a risk of a systemic banking crisis. The results best explain the occurrence of a systemic banking crisis for South American economies included in this study. The results in table (6) above, reveal the following:

- As for the developed economies, inflation turns out to be one of the key factors for explaining the probability of the occurrence of a systemic banking crisis in the South American middle income economies tested.

- The exchange rate (measured as real exchange rate) seems to have played a key role in explaining the occurrence of a systemic banking crisis. There is a clear connection between exchange rates and inflation. As in the case of South America with sudden devaluations as an illustrative example; Argentine defaulted on its sovereign debt and devalued in 2001 (Da-Rocha, Gimenez, \& Lores, 2013). Then Argentine devaluated again in 2014 (Pan, 2015). Brazil devaluated in 1999 (Perry, \& Forero, 2014). Mexico in 1994 (Sachs, Tornell, \& Velasco, 1996). A possible conclusion is that a high real exchange rate is an indicator of an overvalued currency in South America and the crisis starts when the currency is devaluated.

- As expected most of the South American economies that were famous for current account deficits seem to have suffered from a systemic banking crisis. See the table above, (table 6). The current account deficit in itself is not the problem, but if it is covered by borrowing, the cost of serving loans may crowd out investment and lead to sluggish growth. Another risk is if the deficit is covered with so called hot money, which is money that will leave at the slightest disturbance. If the financing of the deficit disappears, then new financing is needed and may be difficult to obtain. Foreign investors may have lost confidence in the economy, therefore making it more difficult to cover the current account with inwards investments. (Obstfeld, \& Rogoff, 2009). Lastly a high current account deficit is a sign of an uncompetitive economy based on consumer spending on imported goods and services (Marchetti, Ruta, \& Teh, 2012). 
- The external debt overhang in South America, as indicated by a positive and statistically significant coefficient for the external debt to GNI (\% ratio). The reason for using external debt to GNI ratio instead of government or public debt to GDP ratio for the South American countries examined is the availability of data. External debt is a good proxy, since a large portion of debt in South America is public and external (Panizza, 2008). This suggests that the higher the amount of external debt (as a percentage of $\mathrm{GNI}$ ), the higher the probability of the occurrence of a systemic banking crisis.

- High levels of central bank reserves is mitigating the risk of a systemic banking crisis as theory suggests. High reserves indicates a more robust banking system and the risk of systemic banking crisis is decreased.

- The other variables remain statistically insignificant and therefore their impact on systemic banking crisis remains unclear.

\section{Conclusion}

The results in regards of inflations being a leading macroeconomic indicator is clear. It is clear that high inflation coincides with banking crisis. The usefulness is also clear. If there is high inflation, keep a keen eye on the banks. The finding is in line with the findings of Glick, and Moreno, (1999), who studied emerging markets in South America and Asia. The regression is also pinpointing inflation as a culprit in the advanced economies. No doubt further research on inflation and its connectivity with systemic crisis warrants further attention.

The real exchange rate is a significant factor for the South American middle income economies. In this case a strong exchange rate does not signify a strong economy but a coming devaluation. Therefore a stronger real exchange rate is related to systemic banking crisis. This study is conforming he studies by Kaminsky, Lizondo, \& Reinhart, (1998) and Kamin and Babson (1999), in their study of Latin American devaluations. The relevance of a currency crisis is clear as stated by Glick, and Moreno (1999). 
In regards to central bank reserves, it is clear that a higher reserves means less risk of a crisis. The result is clearly following common economic reasoning. The more reserves the easier for the central bank to defend its currency and/or act as a lender of last resort.

In an overall conclusion it is clear that the results follow common economic and financial theory. Also the fact that inflations acts universally in diametrically different economies as a leading macroeconomic indicator is also of highest interest. The study also points out that emerging markets, middle income countries in South America are more vulnerable to macroeconomic distortions than the advanced economies. Lastly to be able to predict the next systemic banking crisis, an eye on inflation and external debt as well as the real exchange rate in context of the exchange $r$ ate regime is crucial

\section{References}

Borio, C.E. and Drehmann, M., 2009. Assessing the risk of banking crises-revisited.

Buiter, W.H., Corsetti, G.M. and Pesenti, P.A., 1997. Interpreting the ERM crisis: country-specific and systemic issues.

Chen, Y. C., \& Rogoff, K., 2003. Commodity currencies. Journal of international Economics, 60(1), 133160.

Da-Rocha, J. M., Gimenez, E. L., \& Lores, F. X.,2013. Self-fulfilling crises with default and devaluation. Economic Theory, 53(3), 499-535.

Demirgüç-Kunt, A., \& Detragiache, E., 1998. The determinants of banking crises in developing and developed countries. Staff Papers, 45(1), 81-109.

Feldstein, M.,2002. Argentina's fall. FOREIGN AFFAIRS-NEW YORK-, 81(2), 8-15.

Frankel, J. A., \& Saravelos, G., 2010. Are leading indicators of financial crises useful for assessing country vulnerability? Evidence from the 2008-09 global crisis (No. w16047). National bureau of economic research.

Frenkel, R., \& Rapetti, M., 2008.. Five years of competitive and stable real exchange rate in Argentina, 2002-2007. International Review of Applied Economics, 22(2), 215-226.

Giavazzi, F., \& Spaventa, L., 2011. 11 Why the current account may matter in a monetary union: lessons from the financial crisis in the euro area. The Euro area and the financial crisis, 199.

Glick, R., \& Moreno, R., 1999. Money and credit, competitiveness, and currency crises in Asia and Latin America. Center for Pacific Basin Monetary and Economic Studies, Economic Research Department, Federal Reserve Bank of San Francisco.

Hall, P. A., 2012. The economics and politics of the euro crisis. German Politics, 21(4), 355-371.

Hawkins, J., \& Klau, M.. 2000. Measuring potential vulnerabilities in emerging market economies.

Kamin, S. B., \& Babson, O. D., 1999. Contribution of Domestic and External Factors to Latin American Devaluation Crises: An Early Warning Systems Approach. International Finance Discussion Papers, 645. 
Kaminsky, G., Lizondo, S., \& Reinhart, C. M., 1998. Leading indicators of currency crises. Staff Papers, 45(1), $1-48$.

Laeven, L., \& Valencia, F., 2013. Systemic banking crises database. IMF Economic Review, 61(2), 225270.

Marchetti, J.A., Ruta, M. and Teh, R., 2012. Trade imbalances and multilateral trade cooperation.

Obstfeld, M., 1996. Models of currency crises with self-fulfilling features. European economic review, 40(3), 1037-1047.

Obstfeld, M., \& Rogoff, K., 2009. Global imbalances and the financial crisis: products of common causes.

Pan, F., 2015. Understanding the Argentine Peso's Devaluation in 2014 (Doctoral dissertation, Duke University Durham).

Panizza, U., 2008, March. Domestic and external public debt in developing countries. In United Nations Conference on Trade and Development Discussion Paper (No. 188).

Perry, G. E., \& Forero, A., 2014. Latin America: The Day After. Is This Time Different?. Is This Time Different.

Reinhart, C. M., \& Rogoff, K. S., 2009. The aftermath of financial crises (No. w14656). National Bureau of Economic Research.

Reinhart, C. M., \& Rogoff, K. S., 2010. Growth in a time of debt. American Economic Review, 100(2), 573-578.

Reinhart, C. M., \& Rogoff, K. S., 2013. Banking crises: an equal opportunity menace. Journal of Banking \& Finance, 37(11), 4557-4573.

Rojas-Suarez, L., \& Weisbrod, S. R., 1996. Banking crises in Latin America: Experience and issues.

Sachs, J., Tornell, A., \& Velasco, A., 1996. The Mexican peso crisis: Sudden death or death foretold? Journal of international economics, 41(3), 265-283.

World Bank. (n.d.). Indicators Retrieved April 09, 2016, from http://data.worldbank.org/indicator 